\title{
Population density and habitat preferences of the Black-cheeked Ant-tanager Habia atrimaxillaris
}

\author{
JESSICA S. CORNILS, ISABELL RIEDL, JULIAN FRICKE, MORITZ KATZ and \\ CHRISTIAN H. SCHULZE
}

\begin{abstract}
Summary
The lowland forest on the southern Pacific slope of Costa Rica has an extremely diverse avifauna, including the Black-cheeked Ant-tanager Habia atrimaxillaris. The only known remaining populations of this highly range-restricted species occur in the areas of Piedras Blancas and Corcovado National Park. It is assumed that the population is decreasing due to habitat loss and fragmentation. We assessed the species' population density in a part of the Piedras Blancas National Park using distance sampling (in February-April 2009 and November 2010-January 2011) and territory mapping (November 2010-January 2011). We also examined habitat preferences based on vegetation structure at point count locations. Black-cheeked Ant-tanagers were exclusively found in old-growth forest. The species' likelihood of occurrence at census points increased with forest cover (within a radius of $200 \mathrm{~m}$ around census points), canopy closure, and density of trees (with diameter at breast height $>10 \mathrm{~cm}$ ). Average population density estimated by distance sampling was $24-27$ individuals per $\mathrm{km}^{2}$, which is in accordance with the population size estimated by territory mapping $\left(17-25\right.$ birds per $\left.\mathrm{km}^{2}\right)$. Based on these estimates, an overall population size of $12,432-20,720$ birds is predicted for the remaining $592 \mathrm{~km}^{2}$ lowland forest area of the Golfo Dulce region. The Black-cheeked Ant-tanager was only recorded in old-growth forest, but not in gallery forests embedded in a human-dominated landscape matrix. Since the species appears to avoid forest edges, further forest degradation and fragmentation will have a strong negative impact and should be rapidly reduced by adequate conservation measures.
\end{abstract}

\section{Introduction}

Habitat loss and fragmentation are major threats to rainforest biodiversity (Terborgh 1992, Lawton et al. 1998, Curran et al. 2004, Huang et al. 2007), including birds (Fjeldså 1999, Sodhi and Smith 2007). For $50 \%$ of all threatened bird species in the Americas, it is the only threat that needs to be managed and prevented (Collar et al. 1997). Habitat loss in the tropics is of particular concern given that $70 \%$ of all threatened bird species occur in tropical forests (Sodhi and Smith 2007).

Mesoamerica with its character as a melting pot for northern and southern American species was ranked as one of the 25 primary biodiversity hotspots by Myers et al. (2000). It houses a high percentage of endemic vertebrates and plants. A total of $9 \%$ (29) of the 327 threatened bird species in the Americas have a distribution restricted to Central America, which only represents a small proportion of the whole continent. In terms of range-restricted birds, Costa Rica and Panama have the most diverse species assemblages in the Neotropics (Collar et al. 1997) and they belong among the 15 countries with the most restricted-range bird species in the world (García-Moreno et al. 2007). One of the region's endemic birds, the Black-cheeked Ant-tanager Habia atrimaxillaris (Dwight et al. 1924), has a particularly small distribution range. It only occurs in the lowlands of 
the Golfo Dulce Region in the south-western part of Costa Rica (Slud 1964, Stiles and Skutch 1989, Garrigues and Dean 2007). Due to its extremely small distribution range of only c.500 $\mathrm{km}^{2}$ the species is classified as 'Endangered' (Aubrecht 2008, BirdLife International 2014). The poor knowledge on the species' biology is emphasised by the fact that the first nests of Black-cheeked Ant-tanager were found and described only recently (Huber et al. 2008, Sandoval and Gallo 2009). Furthermore, information on the species' actual conservation status and its habitat preferences is very limited (Aubrecht 2008, Aubrecht and Schulze 2008, Sandoval and Gallo 2009).

Negative effects of human disturbance on forest birds have been reported for many tropical regions (Thiollay 1992, Schulze et al. 2004, Waltert et al. 2005, Gray et al. 2007, Maas et al. 2009, Mordecai et al. 2009). Range-restricted understorey birds are particularly sensitive to anthropogenic forest disturbance (Gray et al. 2007). Therefore, we expect that with ongoing fragmentation of the Pacific lowland forest, remaining populations of the endemic Black-cheeked Ant-tanager will further decline in the next few years. Even well-protected areas such as Corcovado National Park are still strongly affected by deforestation close to their boundaries (Sánchez Azofeifa et al. 2003), which is increasing their isolation from other remaining forest fragments, a phenomenon found to negatively affect most tropical protected areas (Laurance et al. 2012). The range of the Black-cheeked Ant-tanager has declined by approximately 50\% since 1960 (BirdLife International 2014). The only remaining populations are found in Corcovado National Park and in the vicinity of Golfito, particularly in the Esquinas Forest (Piedras Blancas National Park) and the Golfito Faunal Refuge (Schulze and Riedl 2008, Seaman and Schulze 2010, BirdLife International 2014).

Published information on habitat preferences of the Black-cheeked Ant-tanager indicates that the species is restricted to the understorey of dense lowland rainforest (Stiles and Skutch 1989), where it occurs in undisturbed, older secondary and selectively logged forest areas (e.g. Aubrecht 2008). In contrast to other Habia species (e.g. H. gutturalis and H. fuscicauda), the Black-cheeked Ant-tanager forages higher up in the undergrowth and prefers more mature forest (Willis 1966). However, so far no studies have quantitatively analysed the species' habitat preferences, using a standardised survey design. In this study we tried to identify important habitats and forest vegetation structures preferred by the Black-cheeked Ant-tanager. In particular, we addressed the following questions: (I) Does Black-cheeked Ant-tanager prefer mature and old-growth secondary forest, although it can occasionally be observed in other habitats (e.g. beachfront scrub, palms adjacent to forest) (Stiles and Skutch 1989, Capper et al. 1998, Aubrecht 2008)? Slud (1964) noted that they live more in tall secondary growth and broken forests than in the interior of unbroken forests. (2) Does the species avoid forest edges? and (3) to what extent is the species' occurrence related to forest structure (tree density, canopy closure and understorey density)?

Depending on the information used for estimating the species' current population size, the total number of birds is between c.10,000 and 20,000 individuals (BirdLife International 2014). In this study, two different methods - territory mapping and distance sampling - are used to estimate population density in part of the Esquinas Forest. So far such data are missing for this forest reserve. Furthermore, these are the first precise population density estimates, which we use to estimate the species' current total population size.

\section{Methods}

\section{Study area}

The study area is situated in the Golfo Dulce region in the south-western part of Costa Rica. The remaining lowland forests in this region are relatively well protected by the Corcovado National Park (established in 1975) located on the Osa Peninsula and the Piedras Blancas National Park (established in 1994) on the eastern side of Golfo Dulce. These two protected areas are connected through the Golfo Dulce Forest Reserve (established in 1979). Furthermore, a corridor project to improve connectivity between these two National Parks and other protected areas in the vicinity is in progress as part of the project for a Mesoamerican Biological corridor. 
Our study sites were located near La Gamba village $\left(8^{\circ} 42^{\prime} 30^{\prime \prime} \mathrm{N}, 83^{\circ} 11^{\prime} \mathrm{O}^{\prime \prime} \mathrm{W}\right)$ and the La Gamba Tropical Research Station $\left(8^{\circ} 42^{\prime} 61^{\prime \prime} \mathrm{N}, 83^{\circ} 12^{\prime} 97^{\prime \prime} \mathrm{W}\right.$; Figure 1$)$. Here, most areas of flat terrain are covered by human-dominated habitats (pastures, annual cultivation, oil palm plantations, settlements) and secondary forest. On hilly terrain, large parts of the study area are still covered with almost pristine forest (Figure 1 ; for a more detailed description of habitat types see Höbinger et al. 2011).

The forest area in the immediate vicinity of the Tropical Research Station La Gamba is located between elevations of 75 and $350 \mathrm{~m}$ and belongs to the Piedras Blancas National Park. It is easily accessible via an existing trail system (Figure 2) with a total length of $9.2 \mathrm{~km}$. The trails are

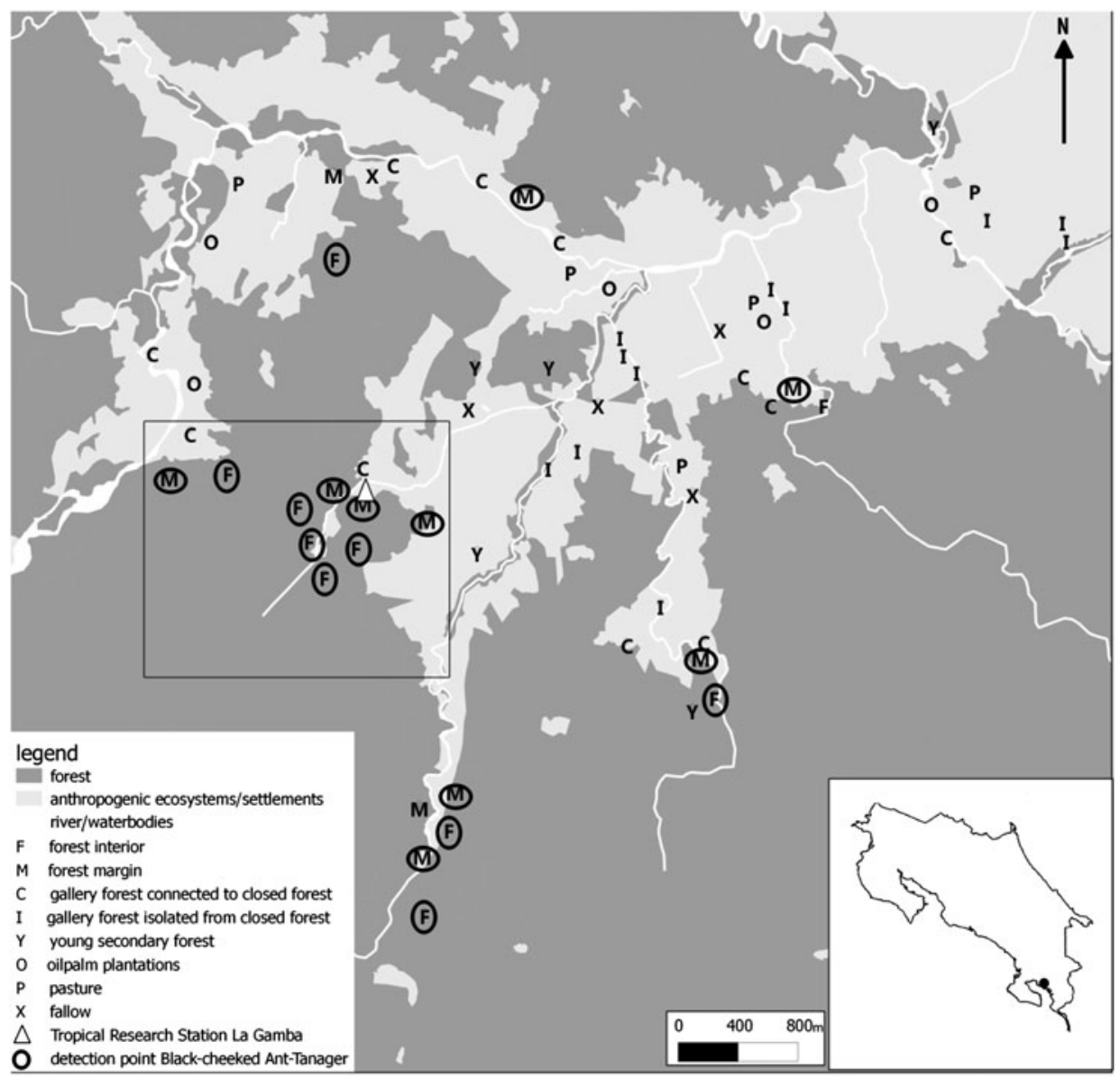

Figure 1 . Maps indicating the location of our study area (inset) and the location of census points used for conducting bird surveys in eight different habitats: FI - interior of old-growth forest, FM - margin of old-growth forest, YSF - young secondary forest, GC - gallery forest strips connected to closed forest, GI - gallery forest strips isolated from closed forest, PP - oil palm plantations, FA - fallows, PA - pastures. Different shading indicates old-growth forest (dark grey), human-dominated habitats (pale grey) and rivers and streams (white). The Tropical Research Station La Gamba is marked by a white triangle. Furthermore, points are indicated at which Black-cheeked Ant-tanagers were recorded. The black square marks the area for which distance sampling was used to quantify population density using a dense trail system (compare Figure 2). 


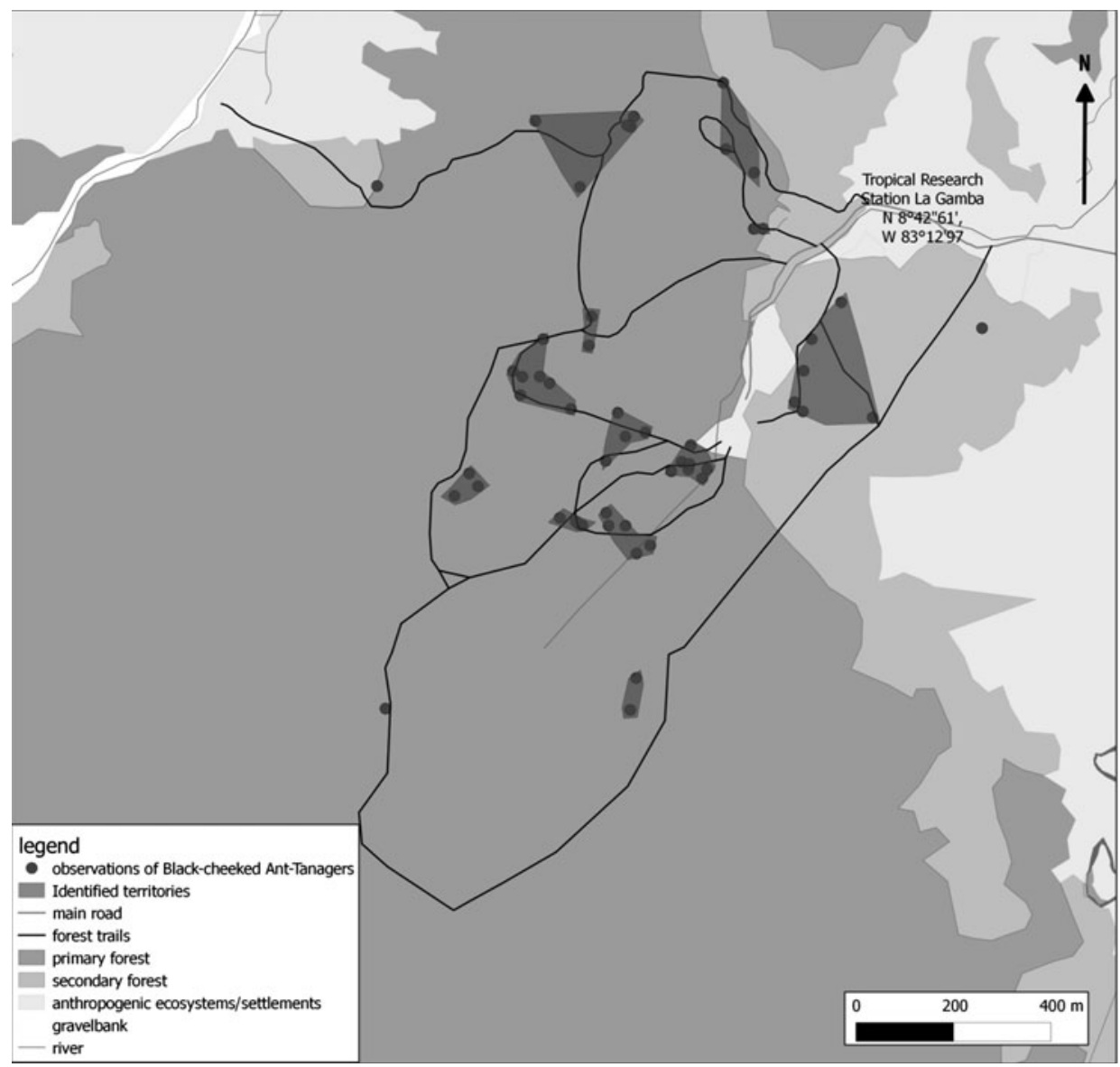

Figure 2. Trail system used for distance sampling and observations of Black-cheeked Ant-tanagers as well as their affiliation to identified territories in the vicinity of the Tropical Research Station La Gamba in 2010/2011.

mainly situated in primary forest ( $76 \%$ of total trail length). The rest of the trails are situated in old-growth secondary forest (with canopy trees $>15 \mathrm{~m}$ high and single emergent trees $>25 \mathrm{~m}$ high) logged $>30$ years ago. The classification of forest types is based on Weissenhofer et al. (2008).

The study area has a mean daily temperature of $28.5^{\circ} \mathrm{C}$; the annual precipitation is about $6,000 \mathrm{~mm}$. The rainy season lasts from August to November; a drier period usually lasts from January to March (Weissenhofer and Huber 2008).

Knowledge of the avifauna of the Golfo Dulce region is summarised in an annotated up-to-date checklist (Tebb 2008).

\section{Point counts}

We established point count locations in eight different habitats: forest interior (FI) and forest margin (FM) of old-growth forest, young secondary forest (YSF), gallery forest connected to closed forest (GC) and isolated (GI), oil palm plantations (PP), fallows (FA) and pastures (PA). For forest types, IO (FI) and II replicate sites (FM, GC, GI) were selected for standardised bird counts 
(Figure 1). All FI sites were located $>50 \mathrm{~m}$ from forest edges within the large forest block of Piedras Blancas National Park. FM sites were located within the transition zone between c.50 $\mathrm{m}$ inside the forest and (semi-)open human-dominated habitats. This distance was chosen because edge effects quantified by abiotic parameters (e.g. air temperature, light) and various vegetation features (e.g. tree stem density, canopy closure, understorey density) mostly do not penetrate further into the forest (reviewed by Murcia 1995). In addition, many forest birds apparently do not respond to edge effects at distances $>50 \mathrm{~m}$ from the forest edge (e.g. examples in Restrepo \& Gómez 1998).

Gallery forests were defined as strips of trees along streams crossing open areas. When in direct contact to closed forest, they were classified as "connected" (GC), otherwise they were defined as "isolated" (GI). The mean length and width $( \pm \mathrm{SD})$ of forest strips was $923( \pm 1,154.37) \mathrm{m}$ and $62.05( \pm 40.33) \mathrm{m}$ for GC sites and 1,974.55 ( \pm 1568.10) $\mathrm{m}$ and $21.77( \pm 40.33) \mathrm{m}$ for GI sites, respectively. The mean distance $( \pm \mathrm{SD})$ to the forest margin was 173.73 ( \pm 154.70$) \mathrm{m}$ for GC sites and $543.00( \pm 141.13) \mathrm{m}$ for GI sites. For all other habitat types (YSF, PP, FA, PA) five replicate sites were selected (Figure 1 ). All sites were selected based on a vegetation map of the study area (Weissenhofer et al. 2008).

Field work was conducted by IR between I November 2008 and 4 October 2010. At each study site, 1o-min point counts were performed from dawn (o5hoo) until 1ohoo (e.g. Blake 1992) using $8 \times 40$ binoculars. All Black-cheeked Ant-tanagers seen or heard within a radius of c. $25 \mathrm{~m}$ around the census point were recorded. Each day, bird counts were carried out at 8-12 census points. To avoid temporal bias in detection rates of birds with time of day, census points were visited in a rotating order (Blake 1992). Each census point was visited 10-12 times in October-February 2008/2009 and 2009/2010 (both dry season) and in June-September 2009 and 2010 (both rainy season).

\section{Habitat variables}

To evaluate the importance of edge effects on the occurrence of Black-cheeked Ant-tanager in old-growth forest sites, forest cover at all FI, FM and YSF sites was quantified within a radius of $200 \mathrm{~m}$ around census points. We used a digital vegetation map of the study area (Weissenhofer et al. 2008) which was updated using aerial photographs from 2009 (OpenLayers plugin of Quantum GIS 1.7.2) and ground surveys to calculate the percentage of old-growth forest within the $200 \mathrm{~m}$ radius around the census points using the software package ArcMap 9.o (ESRI). We prefer to use the term "old-growth forest" (classified as primary forest in Weissenhofer et al. 2008) because it cannot be excluded that individual trees were selectively extracted at some of our sites some decades ago.

To describe vegetation structure at FI, FM and YSF census points, we measured or estimated tree density, canopy closure and understorey density. Tree density was measured as the number of trees (with diameter at breast height $>10 \mathrm{~cm}$ ) within a radius of $25 \mathrm{~m}$ around the census point. To estimate canopy closure, four photographs were taken of the canopy in four different directions from the census point at the margin of the $25 \mathrm{~m}$ radius. Canopy closure was estimated for each photograph to an accuracy of $10 \%$ and then quantified for every census point as the mean of the four estimates. To estimate understorey density, a photograph was taken from breast height towards the ground at eight randomly selected points within the radius of $25 \mathrm{~m}$ around census points. For each of the eight points, understorey density was estimated as the percentage (to an accuracy of $10 \%$ ) of the photograph covered by vegetation. Understorey density at census points was then quantified as the mean of the eight values.

\section{Distance sampling}

We used distance sampling to estimate the population density of Black-cheeked Ant-tanager within old-growth forest. In contrast to traditional bird survey methods, distance sampling is a 
rather simple approach to estimate population density in a defined area (Thomas et al. 2010). We recorded birds along line transects and measured the perpendicular distance between the transect line and all birds detected visually and acoustically with a rangefinder (Nikon Laser 8oo S). There are three main assumptions that have to be fulfilled to achieve reliable density estimates: (I) objects on the transect line are detected with certainty, (2) objects are detected before moving and (3) distance measurements are exact (Thomas et al. 2010).

Transects for distance sampling should be random and straight and distance sampling is based on the assumption that the location of detected animals is independent of the positions of the transect lines, which becomes critical if transects are placed along trails (Thomas et al. 2010). We had to use the network of narrow (c.I m) trails (Figure 2) for the bird survey due to the steep terrain in our study area (Hiby and Krishna 2001, Gale and Thongaree 2006). When conducting distance sampling along transect lines, usually $5 \%$ of the measured distances are truncated, because they contribute little to the abundance estimate (Buckland et al. 2001). We truncated our distance measurements of detected birds at $60 \mathrm{~m}$. In fact, only seven $(4.5 \%)$ of all detections of all detections during the two survey periods were beyond $60 \mathrm{~m}$.

There were two surveys to estimate the population density of Black-cheeked Ant-tanagers in the study area. The first survey was conducted from February to April 2009 by JF and MK, the second survey from November 2010 to January 2011 by JSC. The whole trail network was divided in subunits which were each surveyed 9-28 times in 2009 and 8-12 times in 2010/2011. This resulted in a total of $168 \mathrm{~km}$ transects walked in 2009 and $95 \mathrm{~km}$ in 2010/2011. Surveys were done between dawn (05h3o) and 12 hoo and between 15 hoo and dusk (18hoo).

\section{Territory mapping}

For all Black-cheeked Ant-tanagers detected during transect walks between November 2010 and January 2011, location was determined with a GPS device. Quantum GIS map (Quantum GIS 1.7.3; Quantum GIS Development Team 2011) was then used to visualise the spatial distribution of records and define territories based on spatially clustered observations. When clustered observations were over $50 \mathrm{~m}$ apart from each other and/or individuals were detected on the same transect at approximately the same time in different locations, observations were assigned to two different territories. Single observations of solitary birds were not classified as territories. They may represent juvenile birds still searching for new territories or non-breeding "floaters" rather than birds occupying a territory. However, although we additionally considered behaviour indicating a territory border (e.g. where birds stopped moving in their initial direction), a partly arbitrary interpretation of the spatial distribution of territories cannot be avoided when using such an approach without marking the birds (e.g. by colour rings).

\section{Data analysis}

To compare preferences of Black-cheeked Ant-tanager for different habitats (FI, FM, YSF, GC, GI, PP, FA, PA), we compared the mean number of birds detected per point between all habitats. Abundance per point was quantified as the mean number of birds recorded per 10-min count. Because birds were only recorded at FI and FM sites (see Results), a t-test calculated with the software Statistica 7.I (Statsoft Inc. 2005) was used to test for differences in abundance only between these two forest types.

To test for effects of forest cover, tree density, canopy closure and understorey density on the presence of Black-cheeked Ant-tanager, univariate logistic regressions were calculated with the software Statistica 7.1. Subsequently, generalised linear models (GLMs) with binomial error distribution and logit-link function were used to evaluate effects of habitat variables on the species' occurrence at points. Variables were first tested for multicollinearity. In case of significant correlations between habitat variables only the variables that proved to have a stronger effect on Blackchecked Ant-tanager occurrence were considered in univariate logistic regressions. Then GLMs 
including all remaining variables (standardised) and possible subsets, their corrected Akaike information criterion $\left(\mathrm{AIC}_{\mathrm{c}}\right.$ ) values, $\triangle \mathrm{AIC}_{\mathrm{c}}$ values and $\mathrm{AIC}_{\mathrm{c}}$ weights (a relative measure of support for a model) were calculated with the software R (Barton 2013, R Development Core Team 2013). A higher $\mathrm{AIC}_{\mathrm{c}}$ weight indicates a higher relative likelihood of a model compared to alternative models (Wagenmakers and Farrell 2004). Subsequently, a model averaging was calculated for the 'top model set' (models with $\triangle \mathrm{AIC}_{\mathrm{c}}<4$ ). We did not consider the small gallery forest strips $(\mathrm{GC}$, GI) and all non-forest habitats (PP, FA, PA), where we never recorded Black-cheeked Ant-tanagers, to avoid zero inflation in our models.

Based on the measured perpendicular distances between detected birds and the transect lines, the population density of the Black-cheeked Ant-tanager was estimated by the software Distance 6.0, which fits a detection function to the observed distances (Bibby et al. 1998, Thomas et al. 2002). The analysis started with a truncation of the data at a distance of $60 \mathrm{~m}$ from the transect line. Due to the topography and the dense forest understorey, visual and acoustical detections are very unlikely at distances $>60 \mathrm{~m}$ and resulting distance measurements are too inaccurate.

We used four of the models provided by Distance 6.o (uniform key with cosine adjustments, half-normal key with cosine adjustments, half-normal key with Hermite polynomial adjustments, hazard-rate key with simple polynomial adjustments) which perform best in many studies (Thomas et al. 2010). To select the two models that best fit our data, quantil-quantil plots were used by comparing the detection functions of the models with the actual distribution of our distance data (Thomas et al. 2010). Selected models showed the best fit of the data points with the detection function based on a visual evaluation. This model selection was additionally crosschecked using the ranking of models according to the Akaike information criterion (Thomas et al. 2010). The population density was estimated separately for the two survey periods 2009 and 2010/2011, and by combining data from both survey periods. Because differences in the size of Black-cheeked Ant-tanager groups between both survey periods could potentially result in a difference in detectability, we tested if the number of birds per observation differed between both survey periods using a Mann-Whitney U-test, calculated with Statistica 7.I (Statsoft Inc. 2005).

\section{Results}

\section{Habitat preferences}

Our point census data from different habitats ranging from forest interior towards highly modified land-use systems clearly demonstrate that the Black-cheeked Ant-tanager is restricted to the interior and the margin of old-growth forest. No birds were detected at YSF, GC, GI, PP, FA and PA sites. Although the mean number of birds counted per census point was nearly twice as high at FI (mean number of birds per 1o min count $\pm \mathrm{SD}=0.32 \pm 0.28$ birds) than at FM sites (0.19 \pm 0.19 birds), it did not differ significantly between habitats $(t=1.26, \mathrm{df}=19, P=0.223)$.

\section{Effects of forest cover and vegetation structure at old-growth forest sites}

Calculated logistic regressions indicate that the likelihood of Black-cheeked Ant-tanager occurrence at forest census points increased significantly with increasing forest cover $\left(\chi^{2}=6.23, P=0.013\right.$; Figure 3a), increasing tree density $\left(\chi^{2}=7.16, P=0.007\right.$; Figure $\left.3 \mathrm{~b}\right)$ and increasing canopy closure $\left(\chi^{2}=5.46, P=0.019\right.$; Figure $\left.3 c\right)$. Only understorey density did not affect the species' occurrence $\left(\chi^{2}=2.28, P=0.131\right)$.

Because tree density and canopy closure were highly correlated $(r=0.75, P<0.001)$, canopy closure was excluded from the subsequent GLMs due to its weaker effect on the occurrence of Black-cheeked Ant-tanager according to univariate logistic regressions. GLMs calculated with the three remaining habitat parameters and all possible subsets indicate a prominent effect of forest cover on Black-cheeked Ant-tanager occurrence. This variable remained in all three best models (Table 1 ) and was the variable with the highest explanatory power according to the model averaging approach (Table 2). 

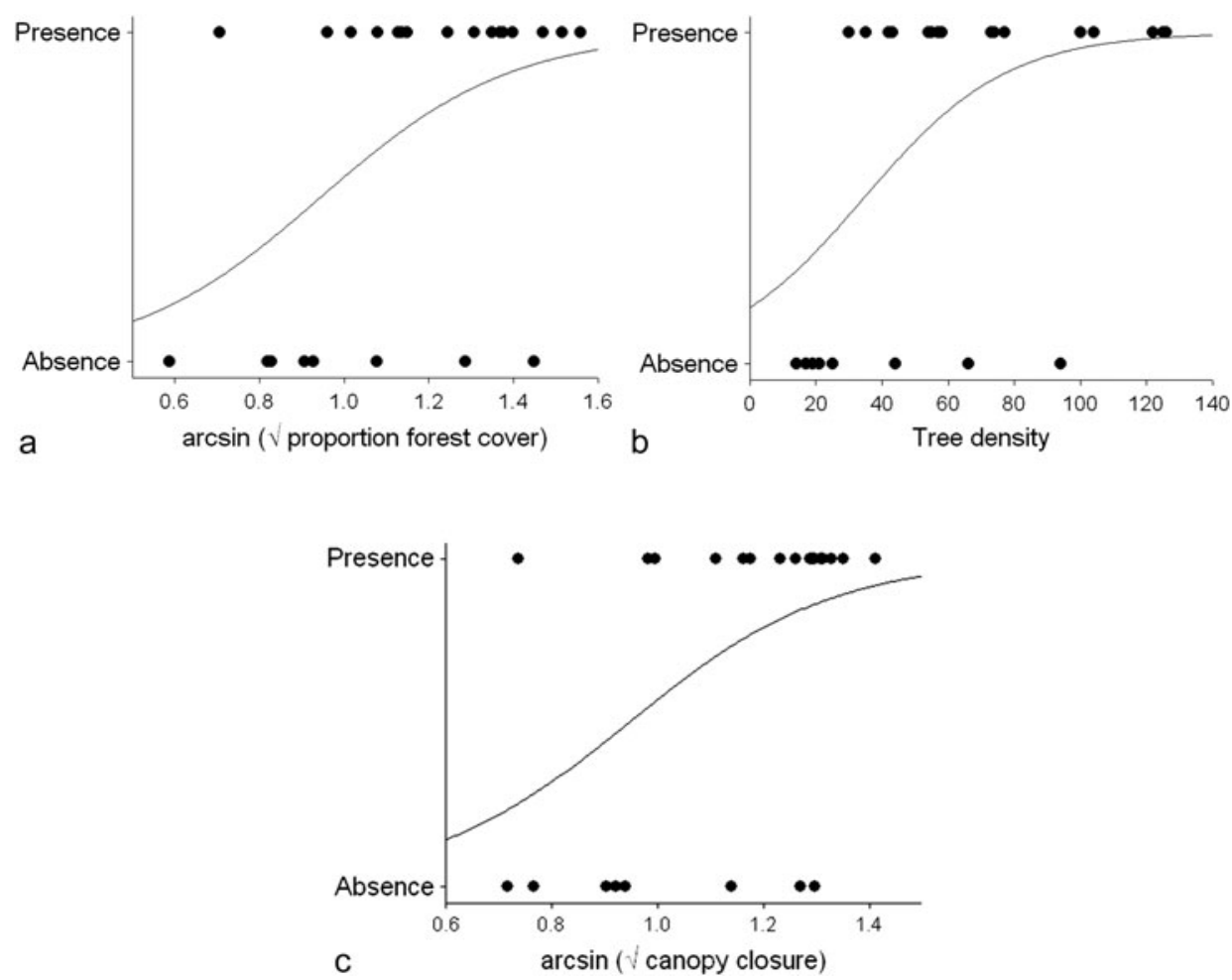

Figure 3. Univariate logistic regressions showing effects of (a) forest cover, (b) tree density and (c) canopy closure on the occurrence of Black-cheeked Ant-tanager at forest census points (FI and FM sites).

\section{Estimating Black-cheeked Ant-tanager density by distance sampling}

During distance sampling, Black-cheeked Ant-tanagers were detected 101 times with 185 birds in 2009 and 53 times with 102 birds in 2010/2011. The mean group sizes of 1.85 (SD \pm 0.96 ) birds in 2009 and $1.93( \pm 0.83)$ birds in 2010/2011 did not differ significantly (Mann-Whitney U-test: $U=2433.50, P=0.407$ ) between the two survey periods.

The two distance sampling models pre-selected through the quantil-quantil plots and the Akaike information criterion (AIC) are the hazard rate simple polynomial model and the half normal cosine model; only the difference between AIC values of both models for the 2009 survey

Table 1. Results of GLMs (with binomial error distribution and logit-link function) calculated to evaluate effects of forest cover, tree density and understorey density (all standardised) on the occurrence of Blackchecked Ant-tanagers at forest census points (FI, FM and YSF sites). GLMs were calculated including all predictor variables and all possible subsets and then ranked according to their corrected Akaike values $\left(\mathrm{AIC}_{\mathrm{c}}\right.$ ). Furthermore, the $\Delta \mathrm{AIC}_{\mathrm{c}}$ values and the $\mathrm{AIC}_{\mathrm{c}}$ weights are provided for each model.

\begin{tabular}{llll}
\hline Included variables & $\mathrm{AIC}_{\mathrm{C}}$ & $\Delta \mathrm{AIC}_{\mathrm{c}}$ & $\mathrm{AIC}_{\mathrm{C}}$ weight \\
\hline tree density, forest cover & $\mathbf{2 6 . 2}$ & $\mathbf{0 . 0 0}$ & $\mathbf{0 . 3 8 9}$ \\
tree density, understorey density, forest cover & $\mathbf{2 6 . 7}$ & $\mathbf{0 . 5 8}$ & $\mathbf{0 . 2 9 1}$ \\
understorey density, forest cover & $\mathbf{2 8 . 0}$ & $\mathbf{1 . 8 5}$ & $\mathbf{0 . 1 5 4}$ \\
tree density & $\mathbf{2 9 . 5}$ & 3.30 & $\mathbf{0 . 0 7 5}$ \\
\hline
\end{tabular}


Table 2. Results of model averaging to quantify effects of each variable on the occurrence of Black-cheeked Ant-tanagers at census points.

\begin{tabular}{lclll}
\hline Included variables & Estimate & SE & $z$ & $P$ \\
\hline forest cover & 1.624 & 0.828 & 1.962 & 0.0498 \\
tree density & 1.920 & 1.128 & 1.702 & 0.0887 \\
Understorey density & -1.068 & 0.751 & 1.423 & 0.1548 \\
\hline
\end{tabular}

was $>2$ (Table 3). Some of the resulting detection probability curves underestimated the number of observed birds close to the transect line and overestimated the number of detected birds in the next distance band (Figure $4 \mathrm{a}-\mathrm{b}, \mathrm{e}-\mathrm{f}$ ). Only the distribution of the detection distances of the 2010/2011 survey is predicted very precisely by the calculated detection probability curves (Figure $4 \mathrm{c}-\mathrm{d}$ ).

Predicted densities were $22.0 \%$ (hazard rate simple polynomial model) and $31.4 \%$ (half normal cosine model) higher for 2010/2011 than 2009. When data from both survey periods were combined, population densities reached values intermediate between the densities estimated for the first and second survey periods. Five of the six models estimated Black-cheeked Ant-tanager densities between c.2I and 27 individuals per $\mathrm{km}^{2}$. A much higher density of c.35.6 birds per $\mathrm{km}^{2}$ was estimated for 2010/2011 by the half normal cosine model (Table 3).

\section{Estimating Black-cheeked Ant-tanager density by territory mapping}

In total 12 territories were identified in our study area. Three single observations were not assigned to a territory (Figure 2). Assuming that territories are occupied by a pair or a pair and at least one juvenile bird, population densities of 17 and 25 birds per $\mathrm{km}^{2}$, respectively, were estimated by territory mapping for our study area of $1.45 \mathrm{~km}^{2}$ (100 $\mathrm{m}$ buffer zone on both sides of the transects). Only one territory and one single observation were located in old-growth secondary forest, all other observations of Black-cheeked Ant-tanager were from the interior of old-growth forest or its margin (Figure 2).

\section{Discussion}

\section{The Black-cheeked Ant-tanager - a forest interior species}

As emphasised earlier (Aubrecht 2008, BirdLife International 2014), our study clearly showed that the occurrence of the Black-cheeked Ant-tanager is restricted to the interior and margin of primary and old-growth secondary forest. The species does not move into younger secondary forests and gallery forest strips, even when they are connected to closed forest. Although the Black-cheeked Ant-tanager can be frequently found close to the forest margin (this study; Seaman and Schulze 2010), our data showed that its occurrence at forest census points was positively related to the percentage of forest cover within a radius of $200 \mathrm{~m}$. This indicates that the species tends to avoid forest edges. The species' preference for old-growth, largely undisturbed forest is further emphasised by our finding that its likelihood of occurrence increased with increasing

Table 3. Akaike information criterion (AIC) values for two different models used to estimate the population density (birds $/ \mathrm{km}^{2}$ ) of Black-cheeked Ant-tanager for the survey periods 2009 and 2010/2010 and for both survey periods combined.

\begin{tabular}{|c|c|c|c|c|c|c|}
\hline \multirow[t]{2}{*}{ Model } & \multicolumn{2}{|c|}{ Survey 2009} & \multicolumn{2}{|c|}{ Survey $2010 / 2011$} & \multicolumn{2}{|c|}{ Both surveys } \\
\hline & AIC & $\operatorname{birds} / \mathrm{km}^{2}$ & AIC & birds $/ \mathrm{km}^{2}$ & AIC & birds $/ \mathrm{km}^{2}$ \\
\hline \multirow{2}{*}{$\begin{array}{l}\text { Hazard rate simple polynomial model } \\
\text { Half normal cosine model }\end{array}$} & 740.52 & 21.08 & 354.42 & 27.04 & 1106.96 & $24 \cdot 34$ \\
\hline & $737 \cdot 75$ & 24.43 & 352.42 & $35 \cdot 59$ & 1105.26 & 26.51 \\
\hline
\end{tabular}



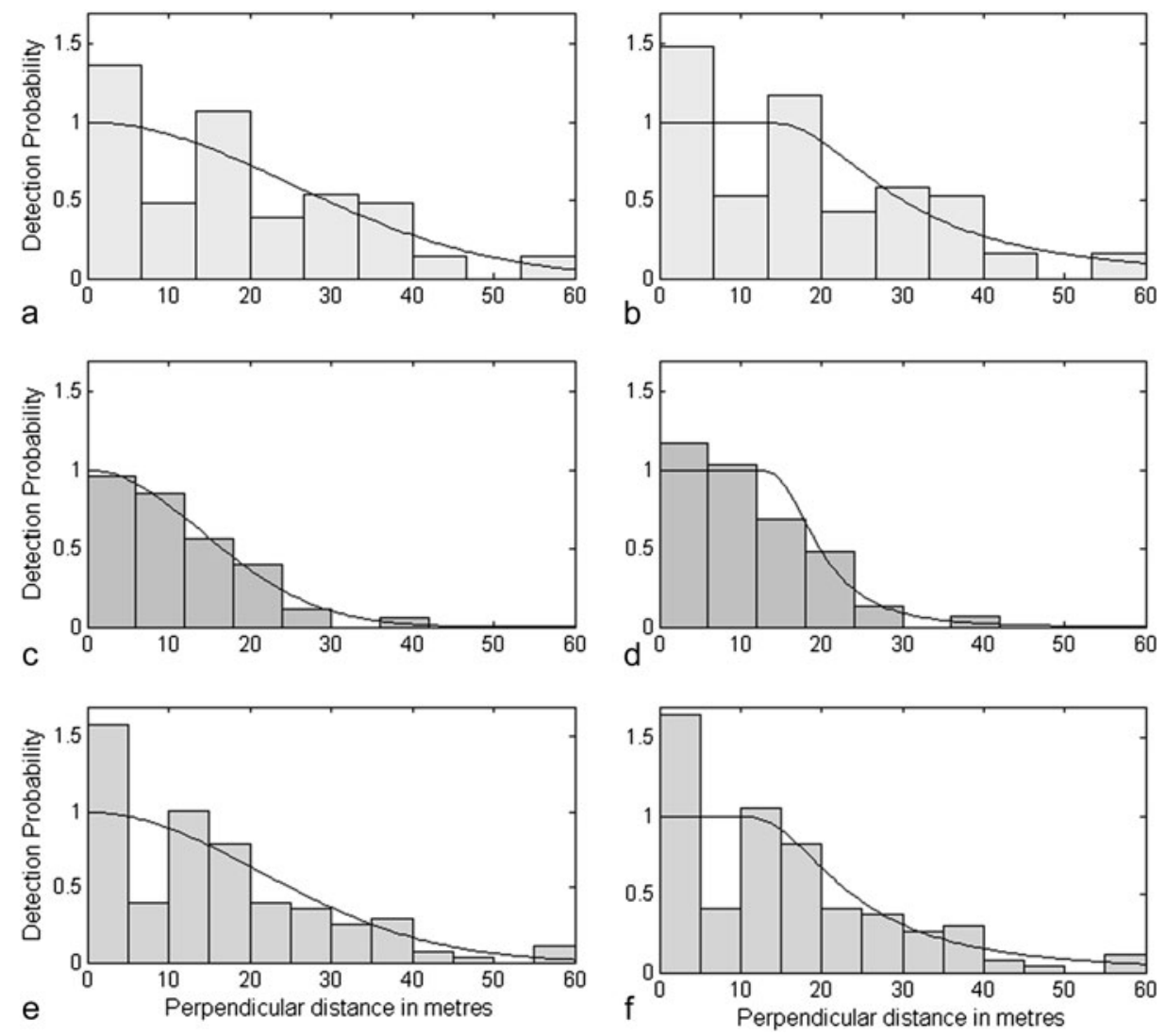

Figure 4. Histograms of detection distances for the transect surveys conducted in (a-b) 2009 and (c-d) 2010/2011 and (e-f) for a combination of both survey periods. Also shown are the corresponding fits of models predicting the detection probability with increasing distance from the transect line using a truncation at $60 \mathrm{~m}$ distance from the transect line. Detection curves in graphs on the left side are predicted by hazard rate simple polynomial model and on the right side by half normal cosine model.

canopy closure. However, a preference for forest sites with a higher density of trees (>10 cm dbh), typical for forest areas or sites disturbed some decades ago, could indicate a weak preference for slightly disturbed sites. This would be partly in accordance with Slud (1964) who noted that the species prefers tall secondary growth and broken forests to the interior of unbroken forests. In our study at least one territory could be located in old secondary forest. If occasional observations of birds in beachfront scrub and palms adjacent to Corcovado National Park (Capper et al. 1998) or in other disturbed habitats at the margin of closed forests (e.g. the botanical garden of the Tropical Research Station La Gamba; pers. obs.) refer to territorial birds. More likely such records may refer to dispersing birds or individuals only occasionally exploiting attractive resources in habitats at the forest margin, which otherwise may be unsuitable for the species.

\section{Population density estimates using distance sampling}

Distance sampling is a method widely used to estimate the population density of species in challenging field conditions (Thomas et al. 2010). It is frequently applied to estimate the population 
density of endangered low density species (e.g. Heydon and Bulloh 1997, Morrogh-Bernard et al. 2003, Hoekman et al. 2011) including understorey forest birds (e.g. Jiménez et al. 2003, Shankar Raman 2003). During both of our survey periods the number of Black-cheeked Ant-tanager observations was higher than the minimum number of 50 detections recommended for estimating population densities with the software Distance (Buckland et al. 1993; but see Oostra et al. 2008).

Our distance sampling data from the survey period 2010/2011 do not indicate that the number of detected birds in the first distance band was affected by the forest trails which were used as transect lines. Additionally, the trail did not obviously act as a barrier to bird movements. Frequently, Black-cheeked Ant-tanagers were observed crossing the small paths (pers. obs.). In contrast, the distribution of measured detection distances from the survey in 2009 (and in consequence the data combining distances sampled in 2009 and 2010/2011) is characterised by an overrepresentation of records in the first distance band and fewer birds observed than expected in the second distance band. However, we do not believe that the unexpectedly high number of Black-cheeked Ant-tanagers detected in the first distance band during the 2009 distance sampling is caused by using forest trails as transect lines. Rather, it may be a result of territorial behaviour during the breeding season which lasts from midJanuary to May (Sandoval and Gallo 2009), the time period of our 2009 survey (FebruaryApril). During the breeding season, birds may approach an observer entering their territory more frequently and, therefore, may move more often towards the transect line before detection. The difference between the two surveys cannot be explained by a higher number of singing birds detected close to the transect line during the breeding season. In fact, only nine detections (of IOI) during the breeding season in 2009 refer to singing birds only detected acoustically. Furthermore, all of these birds were detected at distances of more than 10 $\mathrm{m}$ from the transect line. However, the number of acoustically detected singing birds was obviously too small to affect the shape of the detection curve. The 2010/2011 detection curves had a high detection rate from the zero line up to over $10 \mathrm{~m}$ and then decreased rapidly. The resulting relatively broad shoulder is a feature essential for the accuracy of population density estimation (Buckland et al. 1993). For this reason, the population density estimated by distance sampling for the 2010/2011 survey may be more reliable. However, in fact, both estimates for 2010/2011 and 2009 correspond well to the densities estimated by the number of territories identified in our study area in 2010/2011 (this study) and 2009 (Fricke and Katz unpubl. data).

\section{Population density estimated by territory mapping}

Based on territory mapping in 2010/2011, a total of 12 breeding pairs was estimated for our study area, which corresponds to $17-25$ individuals in our $1.45 \mathrm{~km}^{2}$ study area when assuming $2-3$ birds per family group (Aubrecht 2008). In 2009 the density predicted by distance sampling (21-24 birds) was similar to that achieved by territory mapping (eight territories $\approx 16-24$ individuals; Fricke and Katz unpubl. data).

Other studies (e.g. Gale et al. 2009, Gottschalk and Huettmann 2011, Shankar Raman 2003) comparing territory mapping with point or line distance sampling methods in tropical forests, as well as in forests and open landscapes in the temperate zone, showed that territory mapping produced similar results to the less labour-intensive line distance sampling (Gottschalk and Huettmann 2011, Shankar Raman 2003).

The spatial distribution of territories identified in 2009 (Fricke and Katz unpubl. data) and 2010/2011 (this study) was remarkably similar. Several 2009 and 2010/2011 territories overlapped or were located close to each other. This could indicate a minor turnover of territory owners or that territory sites have to fulfill specific requirements. A low turnover of territory owners and a rather stable spatio-temporal pattern of territories was already recorded for other understorey rainforest birds (Greenberg and Gradwohl 1986, Stouffer 2007). 


\section{Comparison with previous population size estimates}

Based on the assessment of known records, descriptions of abundance and range size, the current population size estimated by IUCN for the Black-cheeked Ant-tanager is 10,000-19,999 individuals (BirdLife International 2014). However, on the distribution map the species is marked as possibly extinct in the area of the Piedras Blancas National Park (IUCN 2012). In fact, our study documented that the species appears to be still abundant in Piedras Blancas National Park. Therefore, when assuming that the species occurs in any old-growth forest in all three protected areas, Corcovado National Park, Golfito Faunal Refuge and Piedras Blancas National Park, the actual distribution range may cover an area of about $592 \mathrm{~km}^{2}$. Considering an average density of $24-27$ individuals per $\mathrm{km}^{2}$ (as estimated by our distance sampling study), the current population size may be between 12,432 and 20,720 birds.

\section{Conservation implications}

The remaining distribution range of the Black-cheeked Ant-tanager is exclusively located within protected areas of Pacific lowland rainforest. Therefore, we do not expect an ongoing decline in range and population area (but see BirdLife International 2014). However, in particular the species' actual status in the Golfito Faunal Reserve should be assessed (Wege and Long 1995). Further sites, which should be surveyed for remaining populations, include the forest area of the Golfo Dulce Forest reserve (IUCN protection category V). Although the species' population size may be currently stable, its small distribution still justifies its current classification as 'Endangered' (BirdLife International 2014).

As documented by our study, Black-cheeked Ant-tanagers tend to avoid forest edges and do not appear to move into highly disturbed forests, but can occasionally be found in old secondary forest. This emphasises that any significant forest disturbance and fragmentation within its remaining distribution will most likely result in local extinctions which can hardly be compensated for by re-colonisation. Gallery forest strips connecting remaining forest fragments can improve landscape connectivity for several forest species (Seaman and Schulze 2010). Although Black-cheeked Ant-tanagers were not recorded in these forest strips by our study, it remains to be proved whether they facilitate movements on a landscape scale. Even very rare movements of perhaps non-territorial dispersing birds, which may remain largely undetected in such matrix habitats, can facilitate the re-colonisation of small isolated forest patches as indicated for small rainforest fragments in Brazil (Stouffer et al. 2011).

However, full protection of the remaining lowland forest at the southern Pacific slope will remain the only way to successfully protect its unique avifauna. There are still opportunities to expand the existing protected forest areas in the Golfo Dulce Region (e.g. compare forested areas indicated on vegetation map in Weissenhofer et al. 2008) and thereby improve the conservation status for the Black-cheeked Ant-tanager and other lowland forest birds. Costa Rica has a high reputation for preserving its biodiversity and is setting standards for conservation networks ( $13.74 \%$ of the country is strictly protected), which play an important role for the protection of threatened species (Sánchez et al. 2009). Hopefully, the endemic Black-cheeked Ant-tanager will also benefit from this exemplary conservation policy. Considering that the Black-cheeked Ant-tanager apparently represents a key species in mixed species flocks, other bird species may benefit too, which would otherwise face the risk of local extinction as documented for Red-crowned Ant-tanager Habia rubica, a key species for maintaining cohesion and stability of mixed-species flocks in coastal Atlantic forest of southern Brazil (Develey and Peres 2000). The disappearance of this species of ant-tanager seems to extirpate this type of association locally. Therefore, conservation plans for nuclear species (such as the Black-cheeked Anttanager) and their habitats should be a high priority (Maldonado-Coelho and Marini 2004).

\section{Acknowledgements}

We would like to thank Andres Felipe Reyes Paez for his encouragement in the field and the Tropical Research Station La Gamba and its team, particularly Maria Luisa Sánchez Porras and 
Roy Sánchez Jimenez, for facilitating our stay in Costa Rica. Research Permission was kindly granted by the Ministry of Environment and Energy (MINAE), Costa Rica. We would further like to thank Werner Huber, Anton Weissenhofer and Daniel Schaber for helping to apply for the research permit. Claudia Schütz kindly provided the data on the forest cover around bird census points. Field work of JC and IR was partly supported by KWA research scholarships of the University of Vienna. We also like to thank Philip Stouffer, an anonymous reviewer and the editor for their valuable comments, which significantly improved our manuscript.

\section{References}

Aubrecht, G. (2008) Habia atrimaxillaris (Dwight \& Griscom) 1924 - The Blackcheeked Ant-tanager. History of an endemic bird species from SW Costa Rica, from discovery to endangered status. Pp. 381-394 in A. Weissenhofer, W. Huber, V. Mayer, S. Pamperl, A. Weber and G. Aubrecht, eds. Natural and cultural history of the Golfo Dulce Region, Costa Rica. Linz, Austria: Biologiezentrum des Oberösterreichischen Landesmuseums.

Aubrecht, G. and Schulze, C. H. (2008) Birds of La Gamba - a call for research and scientific collaboration. Pp. 349-351 in A. Weissenhofer, W. Huber, V. Mayer, S. Pamperl, A. Weber and G. Aubrecht, eds. Natural and cultural history of the Golfo Dulce Region, Costa Rica. Linz, Austria: Biologiezentrum des Oberösterreichischen Landesmuseums.

Barton, K. (2013) MuMIn: Multi-model inference. R package version 1.9.13. http:// CRAN.R-project.org/package $=$ MuMIn.

Bibby, C., Jones, M. and Marsden, S. (1998) Bird surveys. London: Expedition Advisory Centre.

BirdLife International (2014) Species factsheet: Habia atrimaxillaris. http://www.birdlife. org [Accessed: 22 January 2014]

Blake, J. G. (1992) Temporal variation in point counts of birds in a lowland wet forest in Costa Rica. The Condor 94: 265-275.

Buckland, S. T., Anderson, D. R., Burnham, K. P. and Laake, J. L. (1993) Distance sampling: Estimating abundance of biological populations. London: Chapman and Hall.

Buckland, S. T., Anderson, D. R., Burnham, K. P., Laake, J. L., Borchers, D. L. and Thomas, L. (2001) Introduction to distance sampling: estimating abundance of wildlife populations. Oxford, UK: Oxford University Press.

Capper, D. R., Clay, R. P. and Lowen, J. C. (1998) Recent sightings of threatened birds around Corcovado National Park, Costa Rica. Avistamientos recientes de aves amenazadas alrededor del Parque Nacional Corcovado, Costa Rica. Cotinga. 10: 102.

Collar, N. J., Wege, D. C. and Long, A. J. (1997) Patterns and causes of endangerment in the New World avifauna. Ornithol. Monogr. 48: $237^{-260}$.

Curran, L. M., Trigg, S. N., McDonald, A. K., Astiani, D., Hardiono, Y. M., Siregar, P., Caniago, I. and Kasischke, E. (2004) Lowland forest loss in protected areas of Indonesian Borneo. Science 303: 1000-1003.

Develey, P. F. and Peres, C. A. (2000) Resource seasonality and the structure of mixed species bird flocks in a coastal Atlantic forest of southeastern Brazil. J.Trop. Ecol. 16: 33-53.

Dwight, J., Griscom, L. and Smith, A. P. (1924) Descriptions of new birds from Costa Rica. Am. Mus. Novit. 142: 1-5.

Fjeldså, J. (1999) The impact of human forest disturbance on the endemic avifauna of the Udzungwa Mountains, Tanzania. Bird Conserv. Internat. 9: 47-62

Gale, G. A., Round, P. D., Pierce, A. J., Nimnuan, S., Pattanavibool, A. and Brockelman, W. Y. (2009) A field test of distance sampling methods for a tropical forest bird community. Auk 126: 439-448.

Gale, G. A. and Thongaree, S. (2006) Density estimates of nine hornbill species in a lowland forest site in southern Thailand. Bird Conserv. Internat. 16: 57-69.

García-Moreno, J., Clay, R. P. and Ríos-Muñoz, C. A. (2007) The importance of birds for conservation in the Neotropical region. J. Ornithol. 148: 321-326.

Garrigues, R. and Dean, R. (2007) The birds of Costa Rica: A field guide. New York, USA: Cornell University Press, Ithaca.

Gottschalk, T. K. and Huettmann, F. (2011) Comparison of distance sampling and 
territory mapping methods for birds in four different habitats. J. Ornithol. 152: 421-429.

Gray, M. A., Baldauf, S. L., Mayhew, P. J. and Hill, J. K. (2007) The response of avian feeding guilds to tropical forest disturbance. Conserv. Biol. 21: 133-141.

Greenberg, R. and Gradwohl, J. (1986) Constant density and stable territoriality in some tropical insectivorous birds. Oecologia 69: 618-625.

Heydon, M. J. and Bulloh, P. (1997) Mousedeer densities in a tropical rainforest: The impact of selective logging. J. Appl. Ecol. 34: 484-496.

Hiby, L. and Krishna, M. B. (2001) Line transect sampling from a curving path. Biometrics 57: 727-731.

Höbinger, T., Schindler, S., Seaman, B. S., Wrbka, T. and Weissenhofer, A. (2011) Impact of oil palm plantations on the structure of the agroforestry mosaic of La Gamba, southern Costa Rica: potential implications for biodiversity. Agroforestry Syst. 85: 367-281.

Hoekman, S. T., Moynahan, B. J., Lindberg, M. S., Sharman, L. C. and Johnson, W. F. (2011) Line transect sampling for murrelets: accounting for incomplete detection and identification. Marine Ornithol. 39: 35-44.

Huang, C., Kim, S., Altstatt, A., Townshend, J. R. G., Davis, P., Song, K., Tucker, C. J., Rodas, O., Yanosky, A., Clay, R. and Musinsky, J. (2007) Rapid loss of Paraguay's Atlantic forest and the status of protected areas - A Landsat assessment. Remote Sens. Environ. 106: 460-466.

Huber, W., Weissenhofer, A. and Aubrecht, G. (2008) First observations of nest and nestling of the Black-cheeked Ant-tanager Habia atrimaxillaris (Dwight \& Griscom 1924), endemic to the Golfo Dulce rainforests, Costa Rica. Brenesia 70: 53-56.

IUCN (2012) IUCN Red List maps. Explore and discover Red List species ranges and observations. http://maps.iucnredlist.org/map. html?id=106009292. [Accessed 22.05.2012]

Jiménez, I., Londoño, G. A. and Cadena, C. D. (2003) Efficiency, bias, and consistency of visual and aural surveys of curassows (Cracidae) in tropical forests. J. Field Ornithol. 74: 210-216.

Laurance, W. F., Useche, D. C., Rendeiro, J., Kalka, M., Bradshaw, C. J. A., Sloan, S. P.,
Laurance, S. G., Campbell, M., Abernethy, K., Alvarez, P., Arroyo-Rodriguez, V., Ashton, P., Benítez-Malvido, J., Blom, A., Bobo, K. S., Cannon, C. H., Cao, M., Carroll, R., Chapman, C., Coates, R., et al. (2012) Averting biodiversity collapse in tropical forest protected areas. Nature 489: 290-294.

Lawton, J. H., Bignell, D. E., Bolton, B., Bloemers, G. F., Eggleton, P., Hammond, P. M., Hodda, M., Holt, R. D., Larsen, T. B., Mawdsley, N. A., Stork, N. E., Srivastava, D. S. and Watt, A. D. (1998) Biodiversity inventories, indicator taxa and effects of habitat modification in tropical forest. Nature 391: 72-76.

Maas, B., Putra, D. D., Waltert, M., Clough, Y., Tscharntke, T. and Schulze, C. H. (2009) Six years of habitat modification in a tropical rainforest margin of Indonesia do not affect bird diversity but endemic forest species. Biol. Conserv. 142: 2665-2671.

Maldonado-Coelho, M. and Marini, M. Â. (2004) Mixed-species bird flocks from Brazilian Atlantic Forest: the effects of forest fragmentation and seasonality on their size, richness and stability. Biological Conservation 116: 19-26.

Mordecai, R. S., Cooper, R. J. and Justicia, R. (2009) A threshold response to habitat disturbance by forest birds in the Choco Andean corridor, Northwest Ecuador. Biodiv. Conserv. 18: 2421-2431.

Morrogh-Bernard, H., Husson, S., Page, S. and Rieley, J. (2003) Population status of the Bornean orang-utan (Pongo pygmaeus) in the Sebangau peat swamp forest, Central Kalimantan, Indonesia. Biol. Conserv. 110: 141-152.

Murcia, C. (1995) Edge effects in fragmented forests: implications for conservation. Trends Ecol. Evol. 10: 58-62.

Myers, N., Mittermeier, R. A., Mittermeier, C. G., da Fonseca, G. A. and Kent, J. (2000) Biodiversity hotspots for conservation priorities. Nature 403: 853-858.

Oostra, V., Gomes, L. G. L. and Nijman, V. (2008) Implications of deforestation for the abundance of restricted-range bird species in a Costa Rican cloud-forest. Bird Conserv. Internat. 18: 11-19.

Quantum GIS Development Team (2011) Quantum GIS 1.7.3, GNU General Public 
License. http://qgis.osgeo.org. [Accessed: 15.07.2012]

Restrepo, C. and Gómez, N. (1998) Responses of understory birds to anthropogenic edges in a Neotropical montane forest. Ecol. Appl. 8: $170-183$.

R Development Core Team (2013) R: A language and environment for statistical computing. Vienna, Austria: R Foundation for Statistical Computing. http://www.R-project.org/.

Sánchez, J. E., Criado, J., Sánchez, C. and Sandoval, L. (2009) Important Bird Areas Americas - Priority sites for biodiversity conservation. - Costa Rica. Quito, Ecuador: BirdLife International.

Sánchez Azofeifa, G. A., Daily, G. C., Pfaff, S. P. and Busch, C. (2003) Integrity and isolation of Costa Rica's national parks and biological reserves: examining the dynamics of landcover change. Biol. Conserv. 109: 123-135.

Sandoval, L. and Gallo, A. (2009) Description of the nest and eggs of the Black-cheeked Ant Tanager (Habia atrimaxillaris). Wilson J. Ornithol. 121: 635-637.

Schulze, C. H. and Riedl, I. (2008) Bird assemblages of forested and humanmodified countryside habitats in the Pacific lowlands of southern Costa Rica. Pp. 395-408 in A. Weissenhofer, W. Huber, V. Mayer, S. Pamperl, A. Weber and G. Aubrecht, eds. Natural and cultural history of the Golfo Dulce Region, Costa Rica. Stapfia 88. Linz, Austria: Biologiezentrum des Oberösterreichischen Landesmuseums.

Schulze, C. H., Waltert, M., Kessler, P. J. A., Pitopang, R., Veddeler, D., Mühlenberg, M., Gradstein, S. R., Leuschner, C., SteffanDewenter, I. and Tscharntke, T. (2004) Biodiversity indicator groups of tropical land-use systems: comparing plants, birds, and insects. Ecol. Appl. 14: 1321-1333.

Seaman, B. S. and Schulze, C. H. (2010) The importance of gallery forests in the tropical lowlands of Costa Rica for understorey forest birds. Biol. Conserv. 143: 391-398.

Shankar Raman, T. R. (2003) Assessment of census techniques for interspecific comparisons of tropical rainforest bird densities: a field evaluation in the Western Ghats, India. Ibis 145: 9-21.

Slud, P. (1964) The birds of Costa Rica: distribution and ecology. Las aves de Costa Rica: distribución y ecología. Bull. Am. Mus. Nat. Hist. 128: 1-430.

Sodhi, N. S. and Smith, K. G. (2007) Conservation of tropical birds: mission impossible? J. Ornithol. 148: 305-309.

Statsoft Inc. (2005) STATISTICA für Windows [Software-System für Datenanalyse] Version 7.1. www.statsoft.com.

Stiles, F. G. and Skutch, A. F. (1989) A guide to the birds of Costa Rica. New York, USA: Cornell University Press.

Stouffer, P. C. (2007) Density, territory size, and long-term spatial dynamics of a guild of terrestrial insectivorous birds near Manaus, Brazil. Auk 124: 292-306.

Stouffer, P. C., Johnson, E. I., Bierregaard, R. O., Jr. and Lovejoy, T. E. (2011) Understory bird communities in Amazonian rainforest fragments: Species turnover through 25 years post-isolation in recovering landscapes. Plos One 6: e20543.

Tebb, G. (2008) The Birds of La Gamba. Pp. 353-380 in A. Weissenhofer, W. Huber, V. Mayer, S. Pamperl, A. Weber and G. Aubrecht, eds. Natural and cultural history of the Golfo Dulce Region, Costa Rica. Stapfia 88. Linz, Austria: Biologiezentrum des Oberösterreichischen Landesmuseums.

Terborgh, J. (1992) Maintenance of diversity in tropical forests. Biotropica 24: 283-292.

Thiollay, J.-M. (1992) Influence of selective logging on bird species diversity in a Guianan rain forest. Conserv. Biol. 6: 47-63.

Thomas, L., Buckland, S. T., Burnham, K. P., Anderson, D. R., Laake, J. L., Borchers, D. L. and Strindberg, S. (2002) Distance sampling. Pp. 544-552 in A. H. El-Shaarawi and W. W. Piegorsch, eds. Encyclopedia of Environmetrics. Chichester, UK: John Wiley \& Sons.

Thomas, L., Buckland, S. T., Rexstad, E. A., Laake, J. L., Strindberg, S., Hedley, S. L., Bishop, J. R. B., Marques, T.A. and Burnham, K. P. (2010) Distance software: design and analysis of distance sampling surveys for estimating population size. J. Appl. Ecol. 47: 5-14.

Wagenmakers, E. J. and Farrell, S. (2004) AIC model selection using Akaike weights. Psychon. B. Rev. 11: 192-196.

Waltert, M., Bobo, K. S., Sainge, N. M., Fermon, H. and Mühlenberg, M. (2005) 
From forest to farmland: habitat effects on Afrotropical forest bird diversity. Ecol. Appl. 15: 1351-1366.

Wege, D. C. and Long, A. J. (1995) Key areas for threatened birds in the Neotropics. Cambridge, UK: BirdLife International.

Weissenhofer, A. and Huber, W. (2008) The climate of the Esquinas rainforest (survey). Pp. 59-64 in A. Weissenhofer, W. Huber, V. Mayer, S. Pamperl, A. Weber and G. Aubrecht, eds. Natural and cultural history of the Golfo Dulce region, Costa Rica. Linz, Austria: Biologiezentrum des Oberösterreichischen Landesmuseums.
Weissenhofer, A., Huber, W., Koukal, T., Immitzer, M., Schembera, E., Sontag, S., Zamora, N. and Weber, A. (2008) Ecosystem diversity in the Piedras Blancas National Park and adjacent areas (Costa Rica), with the first vegetation map of the area. Pp. 65-96 in A. Weissenhofer, W. Huber, V. Mayer, S. Pamperl, A. Weber and G. Aubrecht, eds. Natural and cultural history of the Golfo Dulce region, Costa Rica. Linz, Austria: Biologiezentrum des Oberösterreichischen Landesmuseums.

Willis, E. O. (1966) Ecology and behavior of the Crested Ant-tanager. Condor 68: 56-71.

\section{JESSICA S. CORNILS*, ISABELL RIEDL, CHRISTIAN H. SCHULZE}

Department of Animal Biodiversity, University of Vienna, Rennweg 14, A-1030 Vienna, Austria.

\section{JULIAN FRICKE, MORITZ KATZ}

Department of Animal Ecology and Tropical Biology, University of Würzburg, Biocenter - Am Hubland, 97074 Würzburg, Germany.

*Author for correspondence; e-mail:jcornils@msn.com

Received 4 February 2014; revision accepted 9 May 2014; Published online 23 September 2014 